\title{
PENDIDIKAN KESEHATAN PADA IBU HAMIL TRIMESTER I TERHADAP UPAYA PENCEGAHAN PREEKLAMPSIA DI PUSKESMAS BANGKALA KABUPATEN JENEPONTO
}

\author{
Andi Hasliani, Rahmawati \\ STIKES Nani Hasanuddin Makassar
}

andi_hasliani@yahoo.com/085396468777

\section{ABSTRACT}

\begin{abstract}
Preeclampsia and eclampsia are complications of ongoing pregnancy, with typical symptoms of hypertension, edema and urine protein. This condition can be prevented since early pregnancy through early detection of risk factors and efforts to promote health through health education about efforts to prevent preeclampsia since trimester I. The purpose of this study is to determine the effect of health education in trimester 1 pregnant women on efforts to prevent preeclampsia in Puskesmas Bangkala Jeneponto Regency. This study uses quantitative analytic research with a quasiexperimental design study with the one group pretest-posttest design approach. This research has been carried out in the Bangkala Puskesmas Work Area Bangkala District Jeneponto District in March to August 2019. The population in this study were pregnant women in the Puskesmas working area and recorded in the medical record, the sampling technique using accidental sampling with a sample size of 50 respondent. The results of this study explain that there are increased efforts to prevent preeclampsia by pregnant women before and after health education is given. The data obtained were performed normality test data to determine the statistical test used, from the results of the normality test data, showed that the data was not normally distributed so that the test used was the Wilcoxon test with a $p$ value of 0.001 smaller than the value of $\alpha=0.05$ so that it could be concluded Significant influence of the provision of health education to efforts to prevent preeclampsia in Bangkala District Health Center Jeneponto.
\end{abstract}

Keywords: Pregnant Mother, Preeclampsia Prevention, Health Education

\section{ABSTRAK}

Preeklampsia dan eklampsia merupakan komplikasi kehamilan berkelanjutan, dengan gejala khas hipertensi, edema dan protein urine. Kondisi ini bisa dicegah sejak awal kehamilan melalui deteksi dini faktor risiko dan upaya promosi kesehatan melalui pendidikan kesehatan tentang upaya-upaya pencegahan preeklampsia yang dilakukan sejak trimester I. Tujuan penelitian ini adalah diketahuinya pengaruh pendidikan kesehatan pada ibu hamil trimester 1 terhadap upaya pencegahan preeklampsia di Puskesmas Bangkala Kabupaten Jeneponto. Penelitian ini menggunakan jenis penelitian kuantitatif analitik dengan studi desain quasi ekspriment dengan pendekatan the one group pretestposttest design. Penelitian ini telah dilaksanakan di Wilayah Kerja Puskesmas Bangkala Kecamatan Bangkala Kabupaten Jeneponto pada bulan Maret sampai Agustus Tahun 2019. Populasi dalam penelitian ini adalah ibu hamil yang berada di wilayah kerja Puskesmas dan terdata di rekam medik, teknik sampling menggunakan accidental sampling dengan besar sampel sebanyak 50 responden. Hasil penelitian ini mejelaskan bahwa ada peningkatan upayaupaya pencegahan preeklampsia yang dilakukan ibu hamil sebelum dan sesudah diberikan pendidikan kesehatan. Data yang diperoleh dilakukan uji normalitas data untuk menentukan uji statistik yang digunakan, dari hasil uji normalitas data, menunjukkan data terdistribusi tidak normal sehingga uji yang digunakan adalah uji Wilcoxon dengan nilai $p$ value 0,001 lebih kecil dari nilai $\alpha=0,05$ sehingga dapat disimpulkan ada pengaruh yang signifikan pemberian pendidikan kesehatan terhadap upaya pencegahan preeklampsia di Puskesmas Bangkala Kabupaten Jeneponto.

Kata kunci : Ibu Hamil, Pencegahan Preeklampsia, Pendidikan Kesehatan

\section{PENDAHULUAN}

Preeklamsia adalah tekanan darah $140 / 90 \mathrm{mmHg}$ setelah kehamilan 20 minggu (akhir triwulan kedua sampai triwulan ketiga) atau bisa lebih awal terjadi (Dainty, 2014). Preeklampsia dan eklampsia merupakan komplikasi kehamilan berkelanjutan, dengan gejala khas hipertensi, edema dan protein urine. Komplikasi preeklampsia terhadap ibu dan bayi yang akan dilahirkan seperti asfiksia, berat bayi lahir rendah dan kematian perinatal. Beberapa faktor ibu sebagai pencetus/risiko terjadinya preeklampsia antara lain umur ibu yang terlalu muda/tua (ibu hamil usia $\leq 20$ tahun dan atau $\geq 35$ tahun), paritas yang tinggi, usia kehamilan, riwayat penyakit dan riwayat obstetrik (Fatkhiyah dkk, 2016).

Angka kematian ibu (AKI) merupakan salah satu indikator untuk melihat derajat kesehatan perempuan. AKI juga merupakan salah satu target yang telah ditentukan dalam Sustainable Development Goals (SDGs) yaitu mengakhiri kematian ibu yang dapat dicegah setidaknya 40 kematian per 100.000 kelahiran hidup yang akan dicapai sampai pada tahun 2030. Berdasarkan laporan menggunakan data dari Sensus, AKI pada tahun 2015 masih sangat tinggi yaitu 305 per 100.000 kelahiran hidup. (profil kesehatan Indonesia Tahun 2017). 
Angka ini masih jauh dari target SDGs. Indikator ini mencerminkan kapasitas sistem kesehatan untuk mencegah dan mengatasi komplikasi yang terjadi selama kehamilan dan persalinan belum efektif (Panduan SDGs Tahun 2016-2030).

Beberapa data dari rumah sakit yang diperoleh dari kegiatan workhop preeklampsia update menunjukkan terjadi pergeseran penyebab kematian di beberapa rumah sakit, salah satunya RS Wahidin Sudirohusodo Makassar yang semula adalah perdarahan telah digantikan oleh preeklampsia dan eklampsia.

Berdasarkan data yang diperoleh di Puskesmas Bangkala Kabupaten Jeneponto ibu hamil dengan faktor risiko preeklampsia yaitu umur saat hamil lebih dari 40 tahun dan primigravida cukup tinggi. Tahun 2017 tercatat 5 ibu hamil yang dirujuk karena mengalami preeklampsia sedangkan pada bulan Januari - Agustus Tahun 2018 terdapat 4 ibu hamil yang mengalami preeklampsia.

Preeklampsia sejatinya bisa dicegah kejadiannya jika dilakukan upaya pengenalan risiko preeklampsia pada pasangan usia subur yang merencanakan kehamilan sejak dini. Pengenalan risiko itu bisa dilakukan melalui pendidikan kesehatan sebagaimana tujuan dari pendidikan kesehatan itu adalah untuk membantu individu, keluarga dan masyarakat dalam meningkatkan kemampuannnya untuk mencapai kesehatan yang optimal.

Preeklampsia merupakan kondisi khusus dalam kehamilan dan dapat menimbulkan komplikasi pada janin dan penyakit ini merupakan penyebab utama kematian maternal. Berdasarkan uraian diatas, penulis tertarik untuk melakukan penelitian dengan judul "Pendidikan kesehatan pada ibu hamil trimester 1 terhadap upaya pencegahan preeklampsia di Puskesmas Bangkala Kabupaten Jeneponto.

\section{METODE}

\section{Desain, tempat dan waktu}

Penelitian ini menggunakan jenis penelitian kuantitatif dengan studi desain quasi ekspriment dengan pendekatan the one group pretest-posttest design. Dalam model penelitian quasi ekspriment ini tidak digunakan suatu pembatasan-pembatasan yang sangat ketat terhadap keharusan randomisasi atau acak. Tes awal dilakukan untuk mengetahui pengetahuan ibu hamil trimester I tentang upaya pencegahan preeklampsia. Selanjutnya akan diberikan perlakuan berupa pendidikan kesehatan tentang upaya pencegahan preeklampsia. Tes akhir dilakukan untuk perubahan perilaku ibu hamil trimester I dalam upaya mencegah preeklampsia.

Penelitian ini akan dilaksanakan di wilayah kerja Puskesmas Bangkala Kabupaten Jeneponto pada bulan Maret sampai Agustus Tahun 2019.

\section{Populasi dan Subjek Penelitian}

Populasi dalam penelitian ini adalah ibu hamil trimester I yang berada di wilayah kerja Puskesmas dan terdata di rekam medik, teknik sampling menggunakan accidental sampling dengan besaran subjek penelitian sebanyak 50 responden yang tersebar di wilayah kerja Puskemas.

\section{Jenis dan Cara Pengumpulan Data.}

Jenis data yang digunakan adalah data primer yang diperoleh dengan cara Peneliti akan memberikan kuesioner untuk mengukur pengetahuan awal (pre test) responden. Setelah memberikan kuesioner, peneliti akan memberikan pendidikan kesehatan tentang upaya-upaya pencegahan pada preeklampsia. Setelah itu akan diberikan post test pertama dengan melakukan kunjungan rumah door to door untuk mengukur pengetahuan responden 1 minggu setelah pendidikan kesehatan, selanjutnya akan ada masa washout yaitu setelah 3 bulan pelaksanaan pendidikan kesehatan akan dibagikan kueisoner untuk mengukur upaya-upaya yang dilakukan responden dalam pencegahan preeklamsia.

\section{Pengolahan dan analisis data}

Data yang terkumpul selama penelitian akan diolah menggunakan SPSS 16,0 . Data yang diperoleh akan diuji normalitas data terlebih dahulu untuk menentukan jenis uji yang digunakan. Jika data terdistribusi normal maka uji yang digunakan adalah uji $t$ berpasangan dan jika data tidak terdistribsui nomal maka uji yang digunakan adalah uji Wilcoxon dengan tingkat kemaknaan $\alpha=0,05$. 
HASIL

\section{Analisis Univariat}

1. Umur

Data responden dengan umur < 20 dan > 35 tahun (berisiko) yaitu 37 Responden (74\%) sedangkan yang berumur 20 - 35 tahun (tidak berisiko) sebanyak 13 responden (26\%).

2. Pendidikan

Data responden yang berpendidikan rendah yaitu 28 Responden (56\%) sedangkan yang berpendidikan menengah sebanyak 22 responden (44\%).

3. Pekerjaan

Data responden dengan pekerjaan IRT sebanyak 47 Responden (94\%) sedangkan pekerjaan wiraswasta sebanyak 3 responden (6\%).

4. Pretest

Data responden sebelum diberikan pendidikan kesehatan, yang melakukan upaya pencegahan preeklampsia yang baik sebayak 3 responden $(6 \%)$, cukup sebanyak 7 responden (14\%) dan yang kurang sebanyak 40 Responden (80\%).

5. Posttest

Berdasarkan tabel 5.5 diperoleh data responden setelah diberikan pendidikan kesehatan, yang melakukan upaya pencegahan preeklampsia yang baik sebanyak 19 responden (38\%), cukup sebanyak 29 responden (58\%) dan yang kurang sebanyak 2 Responden (4\%).

\section{Analisis Bivariat}

1. Uji Normalitas Data

Diperoleh hasil nilai $P$-Value untuk kedua kelompok data adalah kurang dari < 0,05, dengan demikian dapat disimpulkan bahwa distribusi kedua kelompok data adalah tidak normal sehingga uji yang digunakan adalah uji Wilcoxon.

2. Tes statistik pencegahan preeklampsia Diperoleh pengaruh pendidikan kesehatan terhadap pencegahan pre post preeklampsia dengan uji statistik Wilcoxon diperoleh nilai $\rho$ value $=0,00$ jika di bandingkan dengan nilai $\alpha=0,05$, maka $\rho<\alpha$. Hal tersebut menunjukkan bahwa terdapat pengaruh yang signifikan pemberian pendidikan kesehatan pada ibu hamil trimester I terhadap upaya pencegahan preeklampsia di Puskesmas Bangkala Kabupaten Jeneponto.

\section{PEMBAHASAN}

Hasil penelitian yang diperoleh menunjukkan ada pengaruh yang signifikan pemberian pendidikan kesehatan pada ibu hamil trimester I terhadap upaya pencegahan preeklampsia. Hasil analisis univariat dari 50 responden sebelum dilakukan pendidikan kesehatan sebanyak 40 responden (80\%) yang melakukan upaya pencegahan preeklampsia kurang dan setelah diberikan pendidikan kesehatan yang melakukan upaya pencegahan preeklampsia kurang menurun menjadi 2 responden (4\%). Hasil ini diperkuat dengan uji wilcoxon yang dilakukan pada data sebelum dan sesudah dilakukan pendidikan kesehatan. Hasil uji Wilcoxon yaitu 0,000 lebih kecil dari nilai $\alpha$ $=0,05$ sehingga ada pengaruh pendidikan kesehatan pada ibu hamil trimester I terhadap upaya pencegahan preeklampsia.

Meskipun ada peningkatan yang signifikan namun ternyata masih ada 2 responden yang belum melakukan upaya pencegahan preeklmapsia secara maksimal meskipun telah diberikan pendidikan kesehatan. Setelah dilakukan penelusuran pada kedua responden didapatkan jika kedua responden berpendidikan rendah sehingga kemungkinan ibu tidak terlalu memperhatikan kesehatannya termasuk dampak yang bisa terjadi jika mengalami preeklampsia.

Penelitian ini sejalan dengan penelitian yang dilakukan oleh Pudyaningrum PE (2013), yang meneliti pengaruh penyuluhan mengenai preeklampsia terhadap tingkat pengetahuan kader posyandu, hasilnya menunjukkan pre dan posttest ada peningkatan pengetahuan setelah dilakukan penyuluhan.

Penelitian ini juga sejalan dengan penelitian oleh Kurnianingsi I (2017) dengan penelitian pengaruh penyuluhan preeklampsia terhadap motivasi melakukan kunjungan antenatal pada ibu hamil dengan hasil yang diperoleh Ada pengaruh penyuluhan preeklamsia terhadap motivasi melakukan kunjungan ANC pada ibu hamil.

Penyebab preeklampsia belum diketahui secara pasti namun ada beberapa faktor risiko yang berperan yaitu primigravida, riwayat preeklampsia, tekanan darah yang meningkat pada awal 
kehamilan, obesitas, adanay riwayat preeklampsia pada keluarga, kehamilan ganda, riwayat darah tinggi pada maternal, diabetes gestasional, sindroma antifosfolipid, penyakit vaskuler atau jaringan ikat dan usia maternal yang lanjut > 35 tahun (Wiknjosastro, 2010)

Pencegahan atau diagnosis dini preeklampsia dapat mengurangi kejadian dan menurunkan angka kesakitan dan kematian. Untuk dapat menegakkan diagnosis ini diperlukan pengawasan hamil yang teratur dengan memperhatikan kenaikan berat badan, kenaikan tekanan darah dan pemeriksaan urine untuk menentukan proteinuria.

Pencegahan ini belum maksimal dilakukan oleh ibu hamil secara mandiri karena kurangnya pengetahuan ibu tentang preeklampsia. Pada dasarnya upaya pencegahan penyakit pre-eklamsia dapat dilakukan melalui 3 tahapan, yaitu Pencegahan primer yaitu upaya untuk menghindari terjadinya peyakit, pencegahan sekunder yaitu memutus proses terjadinya penyakit yang sedang berlangsung sebelum timbul gejala atau kedaruratan klinis karena penyakit tersebut. Pencegahan tersier yaitu pencegahan dari komplikasi yang disebabkan oleh proses penyakit, sehingga pencegahan ini juga merupakan tata laksana

\section{KESIMPULAN}

Terdapat pengaruh yang signifikan pendidikan kesehatan pada ibu hamil trimester I terhadap upaya pencegahan preeklampsia di Puskesmas Bangkala Kabupaten Jeneponto.

\section{SARAN}

1. Untuk Puskesmas

Memaksimalkan pelayanan antenatal care sesuai dengan standar, terutama penguatan pada promotif dan preventif. Pendidikan kesehatan yang diberikan kepada ibu hamil secara terus menerus selama kehamilannya dapat meningkatkan pengetahuan ibu tentang kesehatannya sehingga dapat melakukan upaya-upaya pencegahan komplikasi kehamilan termasuk preeklampsia.

2. Untuk ibu Hamil

Melakukan kunjungan antenatal minimal 4 kali selama kehamilan sehingga bisa mendapatkan banyak informasi terkait kehamilannya. Informasi yang didapatkan menjadi acuan untuk melakukan upaya-upaya pencegahan komplikasi secara mandiri.

3. Untuk Peneliti Selanjutnya.

Mengkaji lebih dalam terkait preeklampsia sehingga menemukan model yang tepat untuk mencegah sejak dini kejadian preeklampsia pada ibu hamil.

\section{UCAPAN TERIMAKASIH}

\section{Kepada yang terhormat :}

1. Menteri Riset, teknologi dan pendidikan tinggi, Bapak Mohammad Nasir yang telah membiayai penelitian ini melalui Hibah Eksternal Skim Penelitian Dosen Pemula (PDP).

2. Ketua STIKES Nani Hasanuddin Makassar bapak Yasir Haskas yang memberikan dukungan motivasi dan materil.

3. Kepala P3M STIKES Nani Hasanuddin Makassar, Ibu Suarnianti yang selalu memberikan motivasi kepada dosen untuk produktif menghasilkan penelitian dan pengabdian pada msyarakat

4. Kepala Puskemas Bangkala yang telah memberi izin melaksanakan penelitian di Puskesmas Bangkala

5. Responden yang bersedia bekerjasama memberikan data dan informasi sehingga penelitian ini dapat terlaksana.

\section{DAFTAR PUSTAKA}

Dainty, 2014. Asuhan Kebidanan Kehamilan. Surabaya : Bina Rupa Aksara Publisher.

Fatkhiyah N., Khodiyah, Masturoh. 2016. Determinan maternal kejadian preeklampsia (Studi kasus di Kabupaten Tegal, Jawa Tengah). Jurnal Keperawatan Sudirman : Volume 11, No.1, Maret 2016.

Hoelman Dkk, 2016. Susitanable Development Goals-SDGs, Panduan untuk Daerah (Kota dan Kabupaten) dan Pemangku Kepentingan Daerah.

Kurnianingsi I, Suratini, 2017. Pengaruh Penyuluhan Preeklampsia terhadap Motivasi Melakukan Kunjungan ANC pada Ibu Hamil di Puskesmas Banguntapan I Bantul. Program Studi D-IV Kebidanan. Universitas Aisyiyah Yogyakarta. 
http://digilib.unisayogya.ac.id/2990/ 1/NASKAH\%20PUBLIKASI\%20Irma.p df. Diakses 2 September 2019.

Materi Pelatihan Preeklampsia Update, 2018. Early Detection and risk Management. Penyelenggara Rumah Sakit Universitas Hasanuddin.

Pedoman Nasional Pelayanan Kedokteran, 2016. Diagnosis dan Tata Laksana Pre-eklamsia. Perkumpulan Obstetri dan Ginekologi Indonesia. Himpunan Kedokteran Feto Maternal.

Pudyaningrum PE, 2013. Pengaruh Penyuluhan mengenai Preeklampsia terhadap Tingkat Pengetahuan pada Kader Posyandu Kota Semarang. Skripsi Program studi sarjana kedokteran, Univesitas Diponegoro. https://media.neliti.com/media/publ ications/111730-ID-pengaruhpenyuluhan-mengenai-

preeklampsi.pdf, Diakses 2 September 2019

Sopiyuddin Dahlan, 2014. Pintu Gerbang memahami statistic, metodologi dan epidemologi. Jakarta : Sagung Seto.

Stang, 2014. Cara Praktis Penentuan uji statistic dalam penelitian kesehatan dan kedokteran. Jakarta : Mitra Wacana Media.

Wiknjosastro, Hanifa, 2010. IImu Kebidanan. Jakarta: Yayasan Bina Pustaka Sarwono Prawirohardjo. 
Tabel 1.

Karakteristik subjek pada penelitian pendidikan kesehatan pada ibu hamil trimester I terhadap upaya pencegahan preeklamsia di Puskesmas Bangkala Kabupaten Jeneponto.

\begin{tabular}{l|c|c}
\hline \multicolumn{1}{c|}{ Karakteristik Subjek } & N & \% \\
\hline Umur & & \\
$<20$ dan > 35 Tahun & 37 & 74 \\
20-35 Tahun & 13 & 26 \\
\hline Pendidikan & 28 & 56 \\
Rendah & 22 & 44 \\
Menengah & 3 & 6 \\
\hline Pekerjaan & 47 & 94 \\
Wiraswasta & & \\
IRT & 3 & 6 \\
\hline Pretest & 7 & 14 \\
Baik & 40 & 80 \\
Cukup & & \\
Kurang & 19 & 38 \\
Posttest & 29 & 58 \\
Baik & 2 & 4 \\
Cukup & & \\
Kurang & & \\
\hline
\end{tabular}

Tabel 2

Uji Normalitas data

\begin{tabular}{l|r|r|r|r|r|rr}
\hline & \multicolumn{6}{|l|}{ Kolmogorov-smirnov $^{3}$} & \multicolumn{3}{l}{ Shapiro Wilk } & \\
\cline { 2 - 8 } & Statistic & Df & \multicolumn{1}{l|}{ Sig } & Statistic & df & \multicolumn{2}{l}{ Sig } \\
\hline Pretest & .477 & 50 & .000 & .512 & 50 & .000 \\
\hline Postest & .349 & 50 & .000 & .720 & 50 & .000 \\
\hline
\end{tabular}

Tabel 3

Pengaruh pendidikan kesehatan pada ibu trimester 1 terhadap pencegahan preeklampsia

\begin{tabular}{l|l}
\hline & Penecegahan Pre - Pencegahan post \\
\hline $\mathrm{Z}$ & $-6.097^{\mathrm{a}}$ \\
Asymp. Sig. (2-tailed) & .000 \\
\hline
\end{tabular}

